\title{
Following Up on Interests: The Private Agreement Exemption in Ontario Securities Law
}

Mary Condon

Osgoode Hall Law School of York University, mcondon@osgoode.yorku.ca

Source Publication:

Journal of Human Justice Vol 3(2) p.36, 1992

Follow this and additional works at: https://digitalcommons.osgoode.yorku.ca/scholarly_works

Part of the Securities Law Commons

\section{Repository Citation}

Condon, Mary, "Following Up on Interests: The Private Agreement Exemption in Ontario Securities Law" (1992). Articles \& Book Chapters. 2779.

https://digitalcommons.osgoode.yorku.ca/scholarly_works/2779

This Article is brought to you for free and open access by the Faculty Scholarship at Osgoode Digital Commons. It has been accepted for inclusion in Articles \& Book Chapters by an authorized administrator of Osgoode Digital Commons. 


\section{Following up on Interests: The Private Agreement Exemption in Ontario Securities Law Mary G. Condon, Osgoode Hall Law School}

This paper uses insights from cultural theories of regulation and critical legal studies to argue that regulatory outcomes are not adequately explained by the activities of dominant interest groups. A more dynamic conception of the relationship between interests and ideas, especially legal ones, is required. Discursive shifts among languages of entrepreneurship, ownership, fairness, and market credibility are shown to be consequential for the outcome of the reform debate examined, not least because of the importance of these ideas, variously interpreted, in shaping the positions of interest groups.

\section{INTRODUCTION}

A defining feature in much academic analysis of regulatory reform and decision-making is the centrality accorded to the role of interest groups in explaining specific regulatory outcomes (Mitnick, 1980). Thus, public choice economists and pluralist or Marxist political scientists join issue on whether the substantive policies of agencies or the terms of legislative reform reflect the 'capture' of the regulatory process by dominant constituencies of an agency or are rather the embodiment of particular interpretations of the 'public interest' (Stigler, 1988; Bernstein, 1955; Kolko, 1963; Moran, 1986; Phillips and Zecher, 1981; Reschenthaler, 1976). In these rather instrumentalist accounts, the power of an interest group is often defined in terms of access to material or knowledge resources, or as resulting from a privileged location in the regulatory decision-making process. Against this power is pitted the regulatory responsibility to make policy in the 'publicinterest.' From this perspective, identifying an interest position (i.e., that result which is desired by an interest group) can become a somewhat tautological process, in the sense that the outcome of a particular policy debate is assumed to be the result that was sought by a specific powerful group.

This approach to the regulatory process as a sort of equation 'dominant interest group' added to regulatory agency or legislature, equals the desired result - provides a rather impoverished and determinist account of how it is that interests may produce outcomes. In this account, the formulation and presentation of interest positions in policy debates assumes only secondary importance (Derthick and Quirk, 1985). This view of interests as autonomous actors belies evidence that these positions are often built from fragile, contingent coalitions (Thompson, 1982). More importantly, it ignores the fact that interests must operate in the context of particular sets of arguments and ideas. In response to these problems, some commentators have advocated a cultural approach to understanding the regulatory process. Thus, Meidinger proposes: 
a cultural perspective [that] focuses on the understandings that are negotiated and enacted by actors in regulatory arenas. It tends to presume that those understandings are important in their own right, and are not simply reducible to other factors such as pregiven material interests or power. (1987: 366)

Such an 'intermediate analytical position' would, he contends, offer a middle ground between the rigidity of structural models, which assume that actors have no autonomy, and the looseness of individualist approaches to social phenomena. Meidinger's reference to 'shared ideas' should not obscure the fact that views about the regulatory ideas appropriate to a particular context may not be shared, but are often the subject of struggle (Salter, 1982; Hutchinson, 1988; Derthick and Quirk, 1985). However the general point that sets of ideas and languages structure the regulatory enterprise and its objectives, the range of possible outcomes of decision-making, and the way in which regulatory problems are defined, is one worth exploring for the understanding it may add to the relationship between interests and outcomes in the regulatory arena. In order to apply this argument about the importance of ideas to the regulatory context, however, some attention to the relevant sources of the ideas is required. It is here that social-science investigations of the regulatory process cross paths with the concerns of critical legal scholarship.

Obviously, for regulators, a primary source of the ideas animating their activity is the statute(s) which purports to define not only the parameters of their authority to act, but the general objectives they should pursue and the legal strategies to achieve these objectives. Social scientists who analyse the regulatory process often pay insufficiently close attention to the legal ideas and provisions framing the activities of regulators and their constituents. On the other hand, mainstream legal theorists do not concern themselves, by and large, with the social world in which legal ideas are interpreted. However, critical legal scholarship has been very interested in the power and deployment of legal ideas and language, though to date this interest has been largely focused on the adjudicative process in the higher courts. The concern of the present paper is to apply the insights of critical legal theory to an example of regulatory reform in securities markets, in order to understand more clearly the relationship between interests and legal discourse in this arena (Gordon, 1987; Ireland, 1987).

It would be impossible to do justice to the richness of this body of scholarship in the present short discussion (Kelman, 1987; Gordon, 1982, 1984, 1987; Boyle, 1985; Fitzpatrick and Hunt, 1987; Hutchinson, 1991; Trubek, 1986). However certain core propositions can be briefly stated. The first thing to note is that, although these scholars would eschew a rigid distinction between 'law' and 'society;' work in this area has dimensions both internal and external to law (Kelman, 1987: 253). Internally, these scholars have shown in repeated locations of legal decision-making that it is not possible to apply legal rules in a way that produces one 'right' answer, as mainstream legal scholarship purports to demonstrate through 
highly technical forms of argumentation and distinctions between cases. Rather the logic of any legal principle would support a variety of contradictory outcomes (Kelman, 1987: 258). In other words, law is underdetermined and outcomes are contingent on a variety of interpretive factors, including construction of fact situations and manipulation of open-textured legal concepts. Another aspect of the agenda of critical legal studies is to investigate how particular kinds of legal and other languages interact with each other. This is an issue missing from most analyses of the regulatory process, and is particularly fruitful for scholars of economic regulation.

Externally, these supposed certainties of legal rules operate to attach an 'idealised fantasy' of order to social life (Gordon, 1987: 198), while maintaining the fiction of the autonomy of legal decision-making from society at large. This external ordering is achieved both through the patterning and privileging of particular outcomes and through the constitution of individual consciousness in terms of legal categories. Thus, law and society, or law and economy, are not separable entities, but are interpenetrative and interdependent (Fitzpatrick, 1982; Kelman, 1987: 253).

Because of the preoccupation of critical legal scholarship with case by case adjudication, the phenomenon of the existence of interest groups who are often organisations (Hancher and Moran, 1989) and who have ongoing relationships with decision-makers - and the problems involved in specifying interests over periods of time, are rarely addressed (Gordon, 1984: 106). It is assumed that powerful interests are privileged in legal outcomes, with the argument being that 'the judicial emperor, clothed and coiffured in appropriately legitimate and voguish garb by the scholarly rag trade, chooses and acts to protect and preserve the propertied interest of vested white, male and monied power' (Hutchinson, 1991: 184; Gordon, 1987: 199). One obvious question, though, is what happens in regulatory debates within the domain of 'vested white, male and monied power?' More generally, it is arguable that this stance does not sufficiently specify the complexity of the relationship between interests and outcomes and, in particular, the various ways in which interest positions are themselves formulated through legal ideas and categories. Sometimes interest groups are constrained, in the positions they adopt, by the discourses through which they operate and sometimes this constraint defeats them. It is also necessary to recognise that the complexity of the relationship between interests and outcomes is exacerbated by that very indeterminacy of legal discourse to which critical legal scholars point.

\section{INTRODUCING THE PRIVATE AGREEMENT EXEMPTION: CONTEXT AND CHRONOLOGY}

It is proposed to illuminate the relationship between interests and legal discourse by using an' example drawn from debate in the 1970s about certain aspects of the regulation of takeovers under the Ontario Securities 
Act. The reform of the so-called 'private agreement exemption' has generated considerable academic legal commentary, but most of this commentary has failed to address the implications of this reform debate for understanding both the activities of interest groups and the role of language in the regulatory process (Courtright, 1985; Bailey and Crawford, 1983; Rosenfeld, 1972). An overview of the legal context of, and participants in, the debate will be provided at this point, along with a brief chronological guide to the various official reports and legislative bills which considered the matter. Discussion of every stage of the road to reform is required, since part of our concern is to chart the alterations in interest positions and the varieties of legal ideas deployed as debate progressed.

Securities law is a peculiarly North American phenomenon, which originated in a few US states in the first decade of the twentieth century and gathered momentum federally after the Depression. Disclosure of information by companies selling shares to the public, as a way of protecting investors from fraud, along with the establishment of a regulatory agency, the Securities and Exchange Commission (SEC), to enforce this, were core elements of Roosevelt's New Deal (Seligman, 1982). Ontario's securities legislation, administered by an agency known as the Ontario Securities Commission (OSC), has followed a similar pattern. Thus, certain disclosure and other requirements, to be fulfilled by public corporations have been established, ${ }^{1}$ with the concomitant possibility of exemption from those requirements. The conditions under which exemptions may be availed of are specified in the legislation, with a residual category at the discretion of the Securities Commission. This pattern was exhibited in the segment of the 1966 Ontario statute (Ontario Securities Act Stat. Ont. 1966, c.142) putting in place for the first time a scheme for the regulation of takeovers.

A takeover is obviously a significant event in corporate life, with major consequences for shareholders, management and employees. Under the 1966 provisions, a person or company proposing a takeover (the offeror) was required to make certain disclosures about the nature of the offer in a document known as a takeover bid circular - to shareholders of the target company (the offeree), in order to assist them in deciding whether to tender their shares to the bid. Here the principle was established that the primary concern of the regulatory provisions was for protection of the target shareholders, rather than shareholders of the offeror (Gillens, 1986). The statute provided for exemption from the disclosure requirements in a variety of circumstances. That which concerns us here is the exemption in the case of an agreement for the sale of shares between the offeror and a group of controlling shareholders of the offeree company. We shall see shortly what the arguments underlying the availability of this exemption were.

Following passage of the 1966 Act containing this exemption from the takeover bid rules, the issue was re-examined in 1969 in an OSC report, known as the Merger Study, commissioned by the Minister for Financial 
and Commercial Affairs (Courtright, 1985:66). ${ }^{2}$ This report gave the OSC a unique opportunity to set the tone for debate on this issue. After distribution of the Merger Study, which recommended that the situation of the private agreement exemption remain unchanged, Bill 154 was introduced to the legislative assembly in June 1972. However in 1973, a committee of the legislature, the Select Committee on Company Law, again considered the question of the private agreement exemption. In accordance with the majority opinion on the Select Committee, Bill 75 in 1974 retained the exemption unchanged. Then Bill 98, presented in 1975, removed it entirely. This situation persisted through Bills 20 and 30 in 1977, but Bill 7 - which ultimately became the 1978 Securities Act (Stat. Ont. 1978, c.47.) - recovered the exemption, although adding a requirement for a 'follow-up offer' to the remaining (non-controlling) shareholders in certain situations.

Before turning to consider in more detail the terrain of argument around which the issue was considered in the 1970s, let us quickly enumerate the major participants. There is no doubt that the Securities Commission itself had a pivotal role in the whole legislative reform process. It was author of one of the earliest reports to consider the matter and of subsequent drafts of the statute, and also appeared before the various legislative committees that dealt with the issue. As the debate unfolded, other key participants included groups of issuers (corporations which issue shares to the public) and major shareholders, as well as selfregulatory organisations in the field, particularly the Toronto Stock Exchange (TSE) and the Investment Dealers Association (IDA). The role and jurisdiction of these two organisations with respect to the government regulator, the OSC, is worthy of more extensive treatment than can be accorded the topic here (Stenning, 1990). Briefly, both organisations regulate the activities of their members - brokerage and investment houses - under the supervision of the OSC. The TSE has responsibility for operating a stock exchange, again with oversight from the OSC. Both also represent the interests of their members at the regulatory and political levels.

To anticipate a process described more fully in later sections, it might be helpful to note here that the progress of this reform debate was characterised by the emergence of divergent sets of ideas to express the problem and frame its solution. These ideas, whose meaning altered and whose influence waxed and waned throughout the decade, included those of entrepreneurship, ownership, faimess and market credibility.

\section{THE MERGER STUDY: IN PRAISE OF ENTREPRENEURS}

Despite the title by which it is informally known, the major preoccupation of the OSC's Merger Study was the practice of private placement. Under s.58(1) of the 1966 Securities Act, a corporation could circumvent the statutory disclosure requirements occasioned by the initial public offering of shares, by selling the shares to a designated 'exempt purchaser' or by selling a block of shares for an amount exceeding $\$ 97,000$. The rationale for 
these exemptions was that 'sophisticated' investors did not need the protection of the mandated disclosure requirements. The increasing frequency of this practice, said to be prompted by growth in the number of financial institutions (such as mutual funds and investment companies), managing ever-larger pools of personal savings on behalf of 'small' individual or retail investors, was considered problematic by regulators for two reasons. One was that the practice denied individual investors the opportunity to participate independently in initial share offerings. Second, it paved the way for 'backdoor underwritings' whereby private placees (those to whom shares were sold in a private placement) could resell the shares to the public without the need for prospectus disclosure. As it was admitted that the demands of both issuing corporations and financial institutions for the opportunity to undertake these large, cheap and trouble-free transactions had to be accommodated, the Merger Report devoted itself to reconciling this situation with the desirability of continued market participation by small investors under 'protected' conditions.

Thus, the issue with which we are primarily concerned, exemptions for private agreement takeovers, has to be seen both in the context of the drive to accommodate disclosure exemptions generally as well as, more fundamentally, the analytic distinction established by the Merger Report between the 'needs' of small investors and those of large ones. This bifurcation was continued into discussion of the private agreement exemption and, as we shall see, permeated all subsequent consideration of it at the political and regulatory level.

When the Merger Report turned to consider the private agreement takeover, where the offeror makes a deal with a small group of controlling shareholders only, its expressed desire was to 'alleviate the situation in which the minority shareholder now finds himself.' This was defined as one where in 'a competition for control between relative giants,' minority shareholders were at a loss, 'because of competing claims or the atmosphere of uncertainty, to know the best course to follow.' Here the OSC appeared to recognise the issue as one of a power differential among different groups of shareholders, but as we shall see, it concluded that this differential was not conclusive. The committee was obviously unsure what to recommend but was 'loathe' to suggest the 'easiest and least flexible solution' which would be to prohibit all exempt offers. While producing equality this would 'reduce incentive to a common denominator, including the incentive to control, manage, build and then divest to take the benefit of those efforts.'

Despite the much-vaunted advantages of disclosure, no recommendations were made to increase disclosure to minority shareholders in this situation. Nor did the OSC's committee follow up on the opportunity to redress the power imbalances here by recommending the creation of any legal obligation on the part of majority shareholders towards the minority. Rather, it expressed the view that the concept of 'oppression of the minority should be left to corporate law to elaborate.' 
Having summarily dismissed the disclosure disadvantages under which minority shareholders laboured, the OSC report turned its attention to the other disadvantageous aspect of a private agreement takeover, from the minority shareholders' point of view. This was that 'the acquisition of effective control by private agreement [with controlling shareholders] almost invariably involves the payment of a premium to the selling shareholders and in many cases no general offer is made to other shareholders to acquire their shares on the same or substantially similar terms' (Ontario Legislative Assembly, Hodgson Report, 1973: 28). Thus the problem was not just one of lack of disclosure but an advantage extracted by a controlling shareholder, and made possible by the legal rules, in return for saving the offeror the costs and effort of meeting disclosure requirements.

In addressing this inequality of opportunity as between large and small shareholders, the Merger Report turned for inspiration to the situation prevailing under the United Kingdom City Code on Takeovers and Mergers, whereby controlling directors or shareholders could not sell without obtaining an undertaking that the buyer would make a comparable offer to the remaining shareholders. Although the authors of the Merger Report agreed that this requirement had a 'most appealing appearance of fairness,' it was ultimately rejected because it moved 'further down the road towards removing all incentive for entrepreneurship.' It was therefore recommended that the private agreement exemption be retained in the legislation though the number of shareholders with whom agreements could be made should be reduced to fifteen.

Given the construction of the takeover problem by the Merger Study in terms of the competing interests of controlling and minority shareholders, the authors of the study were faced with the choice between reinforcing controlling shareholders' interest in being rewarded for risk or that of minority shareholders in being placed on an equal footing with other shareholders in the corporate enterprise. In undertaking a risk/return calculation on behalf of controlling shareholders, and ultimately privileging the value of incentives over equality, the OSC sidestepped the consequences of its recognition that the ability of large shareholders to capitalise on their control depended on the disempowerment of small shareholders. The legitimacy of this choice was accomplished by defining the controlling shareholder as an entrepreneur, in the absence of empirical information that this was in fact the case, and despite evidence of growing shareholdings by (non-entrepreneurial) financial institutions, managing small-investor capital. In other words, the power of the language of entrepreneurship framed the solutions that could be found to the problems identified by the Merger Study. Finally, while the assumption was made that entrepreneurial activity was good for the economy, no consideration was addressed to the prior question of whether takeovers themselves were similarly beneficial. In an economy characterised by a high concentration of corporate ownership, the argument could be made that increased numbers of takeovers among small groups of shareholders could damage 
economic vibrancy and diversity. This issue was not, however, explored. It has been noted already that a takeover is a significant event for a variety of corporate constituencies. The approach taken by the Merger Study ensured that shareholders were the only relevant constituency for purposes of debate about the consequences of reform.

In the event, Bill 154 of 1972 , drafted by the OSC, reflected the recommendations contained in the Merger Study concerning the private agreement exemption. Although the Bill as a whole generated considerable hostility from interest groups like the IDA and the Canadian Manufacturers Association (CMA), very little attention was paid to the private agreement exemption. Evidently the disadvantages of the exemption to small investors, as enumerated by the OSC, were not compelling enough to provoke a reaction from that quarter. Indeed, representations by small investors were notable by their absence throughout this period.

\section{REVISITING INTERESTS OR WHO OWNS, WINS}

The withdrawal of Bill 154 ended the first phase of 'official' deliberation about the private agreement exemption. The issue was raised publicly again in 1973 by the Legislative Assembly's Select Committee on Company Law. This Committee was reconstituted to, among other things, 'enquire into and review the law relating to mergers or amalgamations.' The key premise of this Committee was that the takeover bid was an important 'vehicle for effecting a business combination' and it evidently regarded the Merger Study treatment of this issue as incomplete. In deciding how to think about takeover bids generally, the Select Committee likewise resorted to English experience with the City Code (Hodgson Report, 1973: 26-27). The Committee explicitly identified an idea underlying some of the City Code's 'general principles of conduct' as relevant to the Ontario situation. This was a concept of 'equity between one shareholder and another' (Hodgson Report, 1973: 27). This concept is resonant of the position rejected in the Merger Study four years previously.

When the Committee turned its attention specifically to the private agreement exemption, it first noted that this form of takeover was a 'common occurrence' in Ontario (Hodgson Report, 1973: 28). The 'dilemma' of minority shareholders was described as one 'where control of the corporation in which they have invested has changed leaving them with two options - to remain as shareholders and accept the changed situation or to sell their shares on the market at a price which will undoubtedly be less than the price received by controlling shareholders.' The policy options identified by the Committee in response to this problem were to (1) allow the situation to continue (2) remove the exemption from the legislation, or (3) continue the exemption but make it conditional on a general offer to all the other shareholders of the same class.

In setting about deciding which option should prevail, the report framed the problem as 'the difficult task of protecting interests.' In adopting a liberal conception of two formally equal interests to be 'bal- 
anced,' the Committee accepted existing definitions of the interests. Yet, as we shall see, it became apparent that the 'serious division of opinion' existing within the Committee as to which of the proposed options was preferable could have potentially profound implications for the very existence of those interests. It should be noted that the division broke down on party political lines, with the Progressive Conservative members on the Committee in the majority and the Liberal and NDP members together in the minority. In the end, the majority favoured the status quo, with the minority advocating that the 'present exemption in the Securities Act should be made conditional on the person acquiring such control making within a reasonable period ... an offer to the remaining shareholders of the same class...' However, what interests us here are the arguments mobilised by the opposing sides in favour of their option. Debate came to centre on the very meaning of share ownership.

The majority argument went as follows: 'shares of a corporation are a form of personal property and ... the owner should be entitled to dispose of them by private agreement on whatever terms he may consider advisable without interference on the part of the legislature....' On the other hand, the minority took the view that, because each share in the capital of a company was the same as every other share of the same class, 'when a controlling shareholder sells control, the thing he is really selling is corporate assets and the right to control the use of those assets and those assets belong to all of the shareholders, not merely the controller.' Thus, according to the minority on the Committee, there were 'valid arguments to be made on a conceptual basis that any premium on the sale of control should be shared by all shareholders.'

Now these differing views about the legal status of shareowners and the consequences of holding control were by no means unique to members of this Legislative Committee. In fact, this particular debate over the nature of corporate shares has a respectably long intellectual history, with the positions of Committee members drawn from two opposing strands of this history (Bailey and Crawford, 1983). As early as 1932, Berle and Means had formulated the 'corporate asset theory' of corporate control whereby the power provided by control was an asset belonging only to the corporation, as opposed to the shareholders. Thus:

The position of a majority shareholder, with his capacity to control, is ... not a 'property right' in the same sense as is his right to participate in dividends, or in liquidation or the like. His control power is really adventitious, a by-product of the corporate capacity to choose a board of directors by less than unanimity. This is why the control power - capacity to choose a management - is a corporate asset, not an individual one. (Berle, 1965:638)

Berle asserted that the holder of control was 'not so much the owner of a proprietary right as the occupier of a power position.' Conceiving of control as a corporate asset might require attention to the position of minority shareholders in a takeover transaction. In contrast, other commentators have made the 'property right' argument and have also pointed 
to the loss of efficiency involved in establishing barriers to corporate control transactions, because 'reducing the controlling shareholder's incentive to sell his control retards the reallocation of the assets of the corporation to people who can use them more productively to the benefit of all of the shareholders' (Posner, 1977:304; Javaras, 1965; Comment, 1964).

Apart from illustrating the dependence of reform proposals on preexisting intellectual ground, this disagreement over the parameters of controlling-share ownership opens the way to important insights into the role of legal discourse in shaping the interests of corporate constituencies, as well as the dependence of corporate organisation and activities on legal constructs. The choice of a particular set of legal ideas (that is, shares as personal or as corporate property) becomes significant in identifying what it means to be a controlling or a minority shareholder. The features of controlling-share ownership, and, presumably, their very existence as an interest group distinct from minority shareholders, turns out to be shifting and contentious ground based on a set of contingent and reworkable legal concepts. Similarly, the arguments for and against the corporate asset theory of control demonstrate the difficulty of identifying conclusively the interests of minority shareholders. Does their interest lie primarily in the efficient reallocation of corporate assets in order to maximise corporate wealth, or is it in the sharing of powers normally associated with control?

Furthermore, the fluidity of the characteristics of controlling or minority shareholding has consequences for the identification of corporate assets, as well as corporate ability to raise capital and make decisions generally. The possibility of continuous reconstruction of the dimensions of ownership, the internal relations and responsibilities of corporate shareholders, and the relationship between the corporation and its shareholders by manipulation of legal concepts all serve to illustrate the malleability of the corporate form itself (White, 1985:34).

Two related points were raised by the majority on the Committee to buttress its position in favour of the status quo. One of these, that to abolish the private agreement would 'reduce the incentive for a person to develop and manage a business" by denying her a "well merited premium,' maintained continuity with the predominant arguments of the OSC's Merger Study. This was a matter of some irony in view of the fact that the OSC's representatives to the Select Committee ${ }^{3}$ indicated that 'their thinking' about exempt offers had changed in the intervening period. They 'now favoured the requirement of a general offer to the remaining shareholders.' The OSC's reasons for its shift of position are not evident from the Select Committee's report. However, a prominent legal commentator on Ontario's securities regulation suggests that the Commission was becoming concerned about the frequency with which controlling interests were changing hands at a premium (Alboini, 1980:684). It appears that the Commission 'indicated in several informal announcements that, as a matter of fairness or ethics, such a purchaser should make an offer of 
equivalent value to the minority shareholders.' It will be recalled that this language of fairness, and the position against control premiums that it implied, had been explicitly rejected in the Merger Study in favour of the then more compelling and economically-oriented discourse of entrepreneurship and risktaking. In any event, the OSC's change of heart was not enough to convince the majority of the Select Committee to depart from its belief in the controlling shareholder's entitlement to dispose of her shares as she chose. The minority on the Committee was content with responding that the argument about entrepreneurship 'may not be as strong as it appears.'

The Merger Study's consideration of a fairness dimension to the problem of the private agreement exemption had been inspired by the English City Code's framing of the relationship between shareholders in this way. Despite the Select Committce's earlier invocation of the City Code's 'general principles' of equity as relevant to Ontario, the majority now disputed their applicability to the private agreement exemption because they did not 'represent a legal enactment but are of persuasive force only.' Furthermore, such principles had been 'developed for application to a financial system whose resources, philosophy and operations are different from our own.' This position is reminiscent of the Merger Study's focus on Canadian entrepreneurs and illustrates the tenacity of this discourse.

\section{NEW PROPOSALS FOR OLD: 1974-1977}

In accordance with the thrust of the majority position, the new Bill 75, introduced in the legislature in June 1974, did not disturb the situation prevailing in Bill 154 whereby an offer to purchase from less than fifteen shareholders was exempt from the takeover bid requirements (Dey, 1975:36). Although few of the interest groups which responded to the introduction of Bill 75 dwelt on the question of takeovers and exempt offers, the brief of one influential group, the TSE, did include reference to takeovers. This suggested that 'further examination' of the takeover situation should be undertaken by itself and the OSC. In discussing the shortcomings of the existing regulatory scheme, the TSE's brief concluded that the Exchange is of the view that the basic principles attaching to takeover bids should include concepts of full disclosure and equality of price and access among all shareholders.' In other words, the TSE favoured the language of equality over that of entrepreneurship.

The momentum established by the strong dissent in the Select Committee's report, the about-turn of the OSC and the support of its position by the TSE bore remarkable fruit in Bill 98, given first reading in the legislature on May 30, 1975. As the OSC's reaction to Bill 75 and its aftermath, it represented a considerable shift from the earlier provisions on exempt takeover offers. The exemption for a takeover by private agreement with less than fifteen shareholders was entirely removed from the Bill. This option, of course, accorded with neither the majority nor the 
minority position on the Select Committee nor the (revised) OSC position of that time. The effect of the removal would be to require a circular to be issued in all takeover situations except those exempted by other provisions of the legislation (Dey, 1975:37). Removing the bargaining advantage for controlling shareholders was presumably intended to discourage any disparity of opportunity as between controlling and minority shareholders. The reasons for OSC adoption of this option are unclear although there is some suggestion that the Commission was a ware that this more drastic option would not survive legislative debate (Bray, 1975:252).

Bill 98 was soon abandoned because an election intervened, but its subsequent manifestations, as Bill 20 (April 1977) and Bill 30 (June 1977), likewise eliminated the private agreement exemption provided for in the 1966 Act. But by now the elimination of the exemption had become an unattractive proposition at the political level. Before Bill 30 could proceed to second reading, it was withdrawn by the Minister of Consumer and Commercial Relations in November 1977. The Minister announced that three aspects of the Bill would be reconsidered 'in light of current conditions' by the newly appointed Chair of the Securities Commission, James Baillie (Ontario Securities Commission Bulletin, December, 1977: 270). One of these aspects was the possible restoration of 'some modified version' of the private agreement exemption. The 'current conditions' appeared to include efforts to enhance rates of capital formation in Canada generally, in a climate of increasingly competitive international trading. An element of this preoccupation was a 'new look' being taken, at the federal level, 'at permitting mergers which increase efficiency and productivity without becoming monopolies.' ${ }^{4}$

Now while the OSC was conducting its review of exemptions from the takeover bid rules, it was required to adjudicate on a matter related to the regulation of issuer bids. This is a situation where an issuer seeks to purchase or redeem its own securities from shareholders as a form of takeover, thus eliminating public participation in the corporation. Although this kind of takeover differs from the private agreement, it has the similar feature of a potentially coercive relationship between powerful, controlling shareholders and those in the minority. It is therefore important to note the Commission's position in Cablecasting (Ontario Securities Commission Bulletin, Feb. 1978: 37) that 'these "insider" transactions ... involve questions of disclosure and questions of fairness that necessitate special rules.'

The significance of this case lies in the support it provides for the proposition that the interests of minority shareholders can be interpreted in diverse ways. Evidence was presented in the hearing before the Commission that the minority shareholders here had been offered a better price for their shares than they would have received in the market. Other evidence was given concerning the efficiency gains that would result for the corporation from a successful issuer bid. Despite this information, the OSC preferred a discourse of fairness for small shareholding, seeing the 
interests of the minority as lying in remedying inequalities of information and access as between themselves and management (Law Society of Upper Canada, 1978: 21-22; Hutchinson, 1991: 197). This result illustrates the replacement of the predominant language of the Merger Report eight years previously with one explicitly rejected at that time. In sum, at the regulatory and political level, this period saw the mobilisation of discourses of both efficiency and faimess. While the regulators (both OSC and TSE) were ad idem in favouring the language of equality, political imperatives were moving in a different direction.

\section{FINAL MOVES}

The OSC's review was completed and Bill 7 was introduced to the House in February 1978. One of the most noteworthy changes from the previous draft was the return appearance of the private agreement exemption, together with the proviso that if the price paid by the offeror exceeded the market price, an offer must be made to purchase all additional shares of the same class for a similar consideration (the so-called 'follow-up' offer). The effect of this provision was to eliminate the premium for controlling shareholders but not the opportunity to make a takeover by private agreement. The Chair of the Securities Commission characterised the private agreement provisions in Bill 7 as 'very clearly ... a compromise between two opposing points of view about how far we should go in this area' (LSUC, 1978:20). At the political level, the Minister for Consumer and Commercial Relations displayed rather more bluntness about the underpinnings of this compromise when he stated

Past versions of this Bill would simply have deleted the private agreement exemption, but it has becomeapparent that this approach would be unduly restrictive, would increase the administrative workload of the Commission and would force businessmen to apply to the Commission for its approval of many transactions even though they would have no element of a control block premium. As a result, flexibility of trading would be decreased and costs of administration and compliance would be increased. (Ontario Securities Commission Bulletin, March, 1978:52)

By identifying the problem to be solved as one of extraction of a premium for controlling shareholder advantage, the government was signalling that the general powers accruing to controlling shareholders, including that of facilitating a takeover without reference to the minority shareholders, were not on its reform agenda. Complete equality among shareholders, as represented by the elimination of the private agreement exemption, was eschewed in favour of considerations of flexibility for issuers and those in control of corporate enterprises.

In the Standing Administration of Justice Committee deliberations of the House in April 1978, after the second reading of Bill 7, various groups had a last chance to influence the outcome of this prolonged attempt to legislate about private agreement takeovers. Two related arguments were mobilised by interest group participants in Committee debate - one to do 
with fairness, the other to do with the legitimacy of the stock market itself. Appearing before the Committee, the OSC's position now seemed to be that a follow-up offer to minority shareholders, in a private agreement takeover at a premium price, was necessary to reinforce the 'credibility' of the market. There is some evidence that this argument was also used by the OSC to mobilise support for the Bill from self-regulatory organisations like the TSE. For example, James Baillie, the Commission Chair, commented that: 'I anticipate that perhaps the TSE and other organisations which feel that a provision like this is necessary to protect the credibility of the markets will be there [at the Administration of Justice Committee] to support it' (LSUC, 1978: 274). In thus responding to evidence of 'the movement of the public away from the equity markets,' the OSC forged a link between its interpretation of fairness for small shareholders and perceived economic consequences (LSUC, 1978: 23). Since no minority shareholders presented themselves to the Administration of Justice Committee, it appears that the Commission saw its own role as one of interpreting and representing the interests of these shareholders. The interpretation of their interests came to centre on the ability of small shareholders to rely on the integrity of the marketplace. The OSC's concern for this reliance contrasts with its previous focus on the economic value of entrepreneurial activity in the Merger Report.

Both the TSE and the IDA indeed rallied to the OSC's call (Hancher and Moran, 1989: 274). The IDA contented itself with endorsing the stance taken in Bill 7 on the exemption, and adverting to the 'considerable controversy' that had arisen in the past over the position of minority shareholders where a premium for control was paid. The TSE considered the 'compromise position' put forward in Bill 7 as the 'proper and beneficial solution' to the problem of private agreement takeovers. By ensuring that 'the public would have the opportunity to share in the premium paid to senior partners,' the compromise would assist in increasing the investor confidence which 'the Exchange has long believed constitutes a vital part of ensuring that the capital markets function properly and effectively.' The TSE went on to make explicit the link between the discourse of market credibility and that of fairness. It understood investor confidence as depending on 'rules enforced against all, which are not only fair but are seen to be fair.' The language of fairness was thus mobilised to reinforce the legitimacy of the market. Similarly, 'the public investor must not be concerned that the rules permit him to be disadvantaged by the insider or control group.' What we see here is a subtle shift in the characteristics and identity of the minority shareholder from a potentially disenfranchised player.in a single corporate enterprise to one of a valuable participant in the marketplace generally. This further transformation of the interests of minority shareholders was again accomplished entirely by the constructions of other debate participants.

Finally, that the language of fairness had achieved ascendancy in the debate is well illustrated by the arguments of a Joint Brief to the Administration of Justice Committee submitted by seven major Canadian corpo- 
rations. These were Algoma, Inco, MacMillan Bloedel, Molson, Noranda, SteelCo, and Trans Canada Pipelines. For convenience they will be here dubbed the Group of Seven. The terms in which this group's views were expressed bear out Baillie's characterisation of opposition to the Bill as 'vociferous' (LSUC, 1978: 274). Their brief will be considered in some detail, since it is instructive in demonstrating both the importance of meaning in the mobilisation of open-textured legal concepts like fairness, and the possibility of using the same concepts, interpreted differently, to advance diverse interests.

\section{THE GROUP OF SEVEN:}

\section{FAIRNESS IN THE EYE OF THE BEHOLDER}

The brief began on a conciliatory note, with Bill 7 characterised as 'very close to being wholly acceptable, both in principle and in workability.' But hostility quickly escalated when private takeover agreements were considered. The follow-up offer should, according to the brief, be completely abandoned. The group went on to assert its 'fundamental and totally negative objection to intervention in private market transactions' to achieve a result different from that 'brought about by market forces.' However, the fact that those market forces were allowed to operate through exemption from the normal legal requirements for takeovers was ignored. The Bill 7 proposals were criticised as founded on the 'false assumption ... that holders of large blocks of shares are in an inherently preferred position relative to holders of small numbers of shares.' Since continued premiums would seem to provide evidence for this 'preferred position,' the Group of Seven resorted to the language of fairness to buttress their argument about the disadvantages suffered by large shareholders.

It was argued that the follow-up offer was more likely to decrease rather than increase fairness. This was because large holdings had a number of disad vantages attached to them, to do with lack of liquidity and the greater risk involved in holding on to securities for long periods of time. The conclusion was therefore that 'there is no possible way of producing fairer results in a myriad of cases than the market place produces.' Here the brief must have been referring to the market place for control as opposed to the market place for shares, since it was clearly not payment of the market price for shares for which the brief was arguing.

The slippery nature of the Group of Seven's understanding of market price was exacerbated by its related argument that a follow-up offer would not actually help the minority shareholder. This was because, to avoid the risk of having to make a follow-up offer, purchasers would either decide not to do the deal or would offer a lower, risk-free price to the controller, giving the purchaser a better price than the 'true market price.' But not having the follow-up offer, of course, would mean that controlling shareholders would not get the 'true market price' either but a premium above it.

We have noted the group's avowed hostility to 'intervention in private 
market transactions' and the 'emasculation of the very basic right of ownership to sell what one owns at a price that one wishes.' It is therefore a matter of some irony that another argument mounted against the followup offer was that it was redundant, 'given free and timely disclosure and stiff insider trading rules.' In other words, the existence of other forms of legal regulation was relied on to discredit the one in dispute. Similarly, it was contended that if a control block holder uses his control to oppress minority shareholders, they can take action to protect themselves.' Since the action referred to here is presumably legal action, these propositions reveal some inconsistencies in the Group of Seven's faith in the market place as a corrective. It remained the group's view that 'people do not require protection from normal, as opposed to artificial, incidents of the market,' but no clarification of the scope and meaning of these terms was provided.

The group's protestations were to no avail, since the follow-up offer section remained in the draft legislation, though the vote in favour was a narrow one (Courtright, 1985:73). The Bill was finally passed into law on June 23, 1978. However, the point to note is that, although the idea of fairness was loose enough to be interpreted in a variety of ways, not all of those interpretations were equally compelling. The attempt by the Group of Seven to link the idea to the imperatives of an anonymous market place proved unconvincing in the face of alternative interpretations in terms of equality for minority shareholders.

\section{CONCLUSION}

Conclusions can be drawn from this example of regulatory reform at a number of different levels. Looking first at the relationship of the interest groups identified in the debate to the ultimate outcome, the first obvious thing to note is that, while controlling shareholders may be considered a powerful interest (especially given high levels of corporate concentration in the Canadian economy), the position they advanced was unsuccessful. Although the power of those shareholders to undertake private agreement takeovers was retained, the follow-up offer, considered to be in the interests of weaker minority shareholders, was legislated despite the fact that no minority shareholders availed of any of the open fora where official decision-makers discussed the matter. Now, it could be said that it was the combined power of the regulators - the OSC and TSE - in favour of the follow-up offer that explains its passage, but the point is that the outcome, especially in a climate of general government concern for more efficient mergers, was unpredictable rather than determined in advance. The OSC's position on the follow-up offer could hardly be considered an entrenched one, since it completely turned around mid-way through the decade. Similarly, it is at least arguable that the TSE's interest in the private agreement exemption was relatively marginal, since this form of takeover was not taking place through the stock exchange. The TSE's position on private agreement takeovers was therefore expressed through the language of general market credibility. The main contribution of the TSE and 
OSC, as we have seen, was rather to avail of various legal and economic discourses to formulate and reformulate the interests of minority shareholders:

It should also be pointed out that the very way the problem was defined - as one of balancing the interests of minority and controlling shareholders - was consequential for the configuration of interests involved in the outcome. There was relatively little attention to the interests of the target corporation as a whole, as distinct from its shareholders, in the issue of private agreement takeovers (Zeitlin, 1989). The offeror corporation remained a shadowy entity also, merely making an appearance in a supporting role in the Group of Seven brief. Thus, close analysis of the debate as it progressed reveals that apparently dominant and stable interest groups displayed rather more inconsistency and fragility than might have been supposed (Thompson, 1982).

A primary aim of the paper is to try to specify the range of connections between interests and legal discourse. Part of this involves showing that the respective power of controlling shareholders on the one hand and the OSC and TSE (on behalf of small shareholders) on the other to achieve their desired outcome depended on the legal ideas and language they mobilised to establish their position. Obviously, the discourse of fairness, as a matter of regulatory doctrine, allows for multiple interpretations. Thus, while both sides used ideas of fairness to formulate their case, the version of it promoted by controlling shareholders (linked as it was to support for entrepreneurship and untrammelled market forces) had become unconvincing and implausible because of the currency that had been achieved by the version linked to equality for minority shareholders. Part of the success of this interpretation was undoubtedly due to the link established with the discourse of market credibility. The general point is that interests can be both constrained and enabled by the discourses through which they operate. The interaction between interests and ideas, then, is a dynamic one in which the power of certain ideas can be sufficient to change the terrain on which decisions affecting interests must be made and on which those interests must make their arguments.

The empirical situation described here is characterised by a complex set of relationships: between the corporation and different shareholder constituencies, among shareholders, and between shareholders and the market. All of these relationships are defined and reconstituted by legal concepts. Thus another aspect of the interconnectedness of interests and legal discourse is the latter's power to create or reinforce the existence of interests in the first place. For example, the availability of the statutory exemption was influential in concretising the opposition of the interests of controlling and minority shareholders and bringing to the surface the potentially adversarial relations between them. But not only did the exemption provide for the power of controlling shareholders to extract premiums for their shares, it also gave a focus for identification of the powerlessness of small shareholders. The construction of minority shareholder interests in diverse ways during the debate is an interesting 
example of how changes in interest positions track changes in discourse. Thus, a particular definition of corporate assets, to include control itself, could be significant in giving a legal basis to minority shareholders' desire - as interpreted by the OSC and TSE - to share in the bounty of the control premium. Later, the language of market credibility was used to reinterpret minority shareholders' interests to mean trust in the integrity of the market place. To reiterate the point made earlier, the power of shifts in prevailing discourses and ideas to change how interests are identified illustrates the malleability of those interests.

But ultimately, the possibility that alternative legal definitions of control could open the way to recognition of the fragmented and disunited nature of the corporate enterprise generally was too much of a nettle to grasp. The legislation of the follow-up offer can be understood as an effort designed to shore up the cracks created in the idea of a consensual, stable corporation by revelations of the divergent and inconsistent interests of different groups of shareholders. It also allowed more fundamental questions about the value of takeovers generally, to corporations, other corporate constituencies, and to the economy, to remain unaddressed.

Finally, despite the Group of Seven's invocation of 'regulation' and 'private ownership' as rigidly separable categories, it should be clear by now that the relationship between law and regulation on the one hand and the corporation and market on the other is a much more interwoven and mutually dependent one. Legal definitions and categories enforce particular versions of the corporate form, its assets and organisation, which are consequently malleable and contingent. The existence of the legislative exemption for private agreement takeovers created the 'market for control' from which controlling shareholders benefited and whose bargaining advantages they were reluctant to surrender. The TSE looked to the regulation of private agreement takeovers as a way of producing the investor confidence necessary for the market to continue to operate (Sunstein, 1990). It is clear that the language of fairness was also important for this purpose. Thus, one of the main accomplishments of a provisional and indeterminate regulatory process is not to constrain or erect 'artificial' barriers to economic activity, but is rather the continuous constitution of the market itself.

The research on which this paper is based was undertaken while the author was a doctoral candidate at the Faculty of Law, University of Toronto. Funding for the research was provided by the Laidlaw Foundation and the Solicitor-General of Canada, through its sustaining grant to the Centre of Criminology, University of Toronto, all of whom I thank for their support. I also thank the Centre for Criminological Research, University of Oxford for its hospitality while this paper was written and Frank Pearce, Laureen Snider and two anonymous reviewers for their comments and encouragement. 


\section{ENDNOTES}

1 Examples of disclosures include those to be made when issuing a prospectus pursuant to the initial public sale of securities or at a time of a 'material change' in corporate affairs.

2 The Report's full title was Report of the Committee of the OSC on the Problems of Disclosure Raised for Investors by Business Combinations and Private Placements. One month prior to the establishment of the OSC's internal committee, the US SEC'sWheat report was published which made recommendations on the same issues as were preoccupying the Merger Study.

3 These were Salter and Bray, Director and Vice-Chair of the OSC respectively, the latter of whom was largely responsible for writing the Merger Report.

4 Speech by the federal Minister of Industry, Trade and Commerce (the Hon. Don Jamieson) to the Third Canadian Financial Conference in June, 1976. The Minister's speech discussed the government's role in creating a 'climate ... which will allow companies to make profits,' especially by 'readjustling] our emphasis on incentives that have largely gone to big business.'

\section{REFERENCES}

Alboini, V.P. Ontario Securities Law. Toronto: DeBoo, 1980.

Bailey, B. and P. Crawford. "The Takeover Bid by Private Agreement: The Follow-up Offer Obligation." Dalhousie Law Journal, 7(3), 1983: 93-168.

Berle, A. "The Price of Power: Sale of Corporate Control." Cornell Law Quarterly, 50, 1965: 628-640.

Bernstein, M. Regulating Business by Independent Commission. Princeton: Princeton University Press, 1955

Boyle, J. "The Politics of Reason: Critical Legal Theory and Local Social Thought." University of Pennsylvania Law Review, 133(6), 1985: 685-780.

Bray, H. "The Ontario Securities Act: Its Policy and Premises." Ontario Securities Commission Bulletin, 1975: 235-270.

Comment, "Sales of Corporate Control and the Theory of Overkill." University of Chicago Law Review, 31, 1963-64: 725-751.

Courtright, J. Securities Regulation of Takeover Bids in Canada. Calgary: Carswell, 1985.

Derthick, M. and P. Quirk. The Politics of Deregulation. Washington: Brookings, 1985.

Dey P. "Securities Reform in Ontario: The Securities Act 1975." Canadian Business Law Journal, 1, 1975: 20-53.

Fitzpatrick, P. "Marxism and Legal Pluralism." Australian Journal of Law and Society, 1, 1982-83:45-59.

Gillen, M. "Economic Efficiency and Takeover Bid Regulation." Osgoode Hall Law Journal, 24 (4) 1986: 919-959.

Gordon, R. "Unfreezing Legal Reality: Critical Approaches to Law." Florida State University Law Review, 15(2), 1987: 195-220.

Gordon, R. "Critical Legal Histories." Stanford Law Review, 36, 1984: 57-125.

Gordon, R. "New Developments in Legal Theory," D. Kairys (ed.) The Politics of Law: A Progressive Critique. New York: Pantheon Books, 1982: 281-293.

Hancher, L. and M. Moran. "Organising Regulatory Space." Leigh Hancher and Michael Moran (eds.). Capitalism, Culture and Economic Regulation. Oxford: Clarendon Press, 1989: 271-299.

Hutchinson, A. Dwelling on the Threshold. Toronto: Carswell, 1988.

Hutchinson, A. "Crits and Cricket: A Deconstructive Spin (Or Was It a Googly?)" R. Devlin (ed.). Canadian Perspectives on Legal Theory. Toronto: Emond Publications, 1991: 181-205. 
Ireland, P., I. Grigg-Spall and D. Kelly. "The Conceptual Foundations of Modern Company Law." Peter Fitzpatrick and Alan Hunt (eds.). Critical Legal Studies. Oxford: Basil Blackwell, 1987: 149-165.

Javaras, G. "Equal Opportunity in the Sale of Controlling Shares: A Reply to Professor Andrews." University of Chicago Law Review, 32, 1965: 420-428.

Kelman, M. A Guide to Critical Legal Studies. Cambridge: Harvard University Press, 1987.

Kolko, G. The Triumph of Conservatism: A Reinterpretation of American History. Glencoe: Free Press, 1963.

Law Society of Upper Canada. New Securities Legislation, Lectures/Edited Panel Discussion. Toronto: Law Society of Upper Canada, 1978.

Meidinger, E. "Regulatory Culture: A Theoretical Outline." Law and Policy, 9, 1987:355383.

Mitnick, B. The Political Economy of Regulation. New York:Columbia University Press, 1980.

Moran, M. "Theories of Regulation and Changes in Regulation: The Case of Financial Markets." Political Studies, 34, 1986: 185-201.

Ontario Legislative Assembly Select Committee on Company Law. Report on Mergers, Amalgamations and Certain Related Matters, (Hodgson Report). Toronto: Queen's Printer, 1973.

Ontario Securities Commission. Report of the Committee of the OSC on the Problems of Disclosure Raised for Investors by Business Combinations and Private Placements, (Merger Study). Toronto: Dept. of Financial and Commercial Affairs, 1970.

Phillips, S.M. and J.R. Zecher. The SEC and the Public Interest. Cambridge: MIT Press, 1981.

Posner, R.A. Economic Analysis of Law, (2nd ed.). Little Brown: Toronto, 1977.

Reschenthaler, G.B. "Regulatory Failure and Competition." Public Administration, 1976: $466-486$

Rosenfeld W.P. "Corporate Acquisitions." Special Lectures on Company Law, Law Society of Upper Canada. Toronto: De Boo, 1972: 367-389.

Salter, R.L. "The Value Debate in Regulation." Osgoode Hall Law Journal, 20(3), 1982: 485-511.

Seligman, J. The Transformation of Wall Street. New York: Houghton Mifflin, 1982.

Stenning, P., C.D. Shearing, S.M Addario and M.G. Condon. "Controlling Interests: Two Conceptions of Order in Regulating a Financial Market." M.L. Friedland (ed.), Securing Compliance. Toronto: University of Toronto Press, 1990: 88-119.

Stigler, G. "The Theory of Economic Regulation." George Stigler (ed.), Chicago Studies in Political Economy. Chicago: University of Chicago Press, 1988: 209-233.

Sunstein, C. After the Rights Revolution: Reconceiving the Regulatory State. Cambridge: Harvard University Press, 1990.

Thompson, G. "The Firm as a 'Dispersed' Social Agency." Economy and Society, 11(3), 1982: 233-250.

Trubek, D. "Where the Legal Action Is: Critical Legal Studies and Empiricism." Terence Daintith and Gunther Teubner (eds.), Con tract and Organisation. Berlin: de Gruyter, 1986.

White, J.B. Heracles' Bow. Madison: University of Wisconsin Press, 1985.

Zeitlin, M. The Large Corporation and Contemporary Classes. Cambridge: Polity Press, 1989. 